\title{
Addressing the Challenge of Overlapping Claims in Implementing the Vancouver Island (Douglas) Treaties
}

\author{
Brian Thom University of Victoria
}

\begin{abstract}
Indigenous social and legal orders are a source for addressing the challenge of overlapping claims in exercising historic treaty rights in the territories of neighbouring nontreaty Indigenous Peoples. The Vancouver Island Treaties (also known as the Douglas Treaties) of the 1850 s made commitments that signatory communities could continue to hunt on unoccupied lands and carry on their fisheries as formerly. Today, as urban, agricultural and industrial forestry have constrained where people can exercise their treaty rights locally, individuals from these nations exercise harvesting rights in "extended territories" of their neighbours. Through detailing several court cases where these treaty rights were challenged by the Crown and the texts of modern-day treaty documents, I show how Coast Salish people continue to draw on local values and legal principles to articulate their distinctive vision of territory and community, both engaging and subverting divisive "overlapping claims" discourses. Not only First Nations but the state, through the judiciary, Crown counsel and land claims negotiators, also, at times, acknowledge and recognise the principles of kin and land tenure that are the foundation for addressing the challenges of overlapping claims.
\end{abstract}

Keywords: Indigenous territory, Douglas Treaties, modern-day treaty negotiations, Indigenous law, hunting rights

Resumé : Les ordres sociaux et juridiques autochtones constituent un point d'appui pour relever le défi du chevauchement des négociations dans l'exercice des droits issus des traités historiques sur les territoires des peuples autochtones voisins non visés par un traité. Les Traités de l'île de Vancouver (également connus sous le nom de Traités Douglas), signés dans les années 1850, permettaient aux nations signataires de continuer à chasser sur les terres inoccupées et à pêcher comme autrefois. Aujourd'hui, alors que la foresterie urbaine, agricole et industrielle a réduit le territoire d'exercice des droits issus des traités au niveau local, les membres de ces nations exercent leurs droits de récolte sur les «territoires étendus » de leurs voisins. En détaillant plusieurs affaires judiciaires dans lesquelles ces droits ont été contestés par la Couronne ainsi que les textes des traités modernes, je montre comment les Coast Salish continuent à s'inspirer des valeurs et des principes juridiques locaux pour exprimer leur vision particulière du territoire et de la communauté, et ce en investissant et en subvertissant tout à la fois les discours clivants sur les « chevauchements des négociations ». Il arrive parfois que l'État, par l'intermédiaire du pouvoir judiciaire, des avocats de la Couronne et des négociateurs des revendications territoriales, reconnaisse lui aussi les principes de parenté et de régime foncier qui constituent le point d'appui pour relever le défi du chevauchement des négociations.

Mots clés : territoire autochtone, Traité Douglas, processus de négociation des traités modernes, traditions juridiques autochtones, droits de chasse

\section{Introduction}

ne of the key challenges of implementing historic treaties, establishing modern-day treaty relationships and recognising ongoing Aboriginal rights is the problem of so-called overlapping claims. The contemporary topography of Indigenous territories is a complex terrain in which the rights, duties, obligations and authorities that flow from various historic treaty, nontreaty and modern-day treaty relationships play out not only between the state and Indigenous communities but among members of those communities who are navigating their territorial rights (Miller 2014; Nadasdy 2012; Thom 2009). Indigenous communities exercising their vision of territorial governance and individuals from those communities exercising their land-based rights act in ways that are consistent with Indigenous social and legal orders, yet they are often thrown into conflict through mainstream political and legal discourses of overlapping claims, which demand answers to questions such as: Which treaty are you from? Whose territory are you exercising treaty rights in? What is the extent of your self-government jurisdictions over treaty rights?

To gain insight into these broader problems, I will discuss the challenges of implementing treaty relationships in the specific context of the Crown's commitments made in the historic Vancouver Island Treaties. These treaties, also frequently referred to in the literature and by the courts as the Douglas Treaties, 
after James Douglas, then governor of the colony of Vancouver Island (Duff 1969; Foster 1989; Frogner 2010; Vallance 2015), were made from 1850 to 1854 mainly on the southern tip of Vancouver Island. The text of these treaties describes a treaty relationship over a very small geographic area of Coast Salish peoples' territories (see Figure 1), and are recognized today as involving the contemporary Lekwungen (Songhees, Esquimalt), WSÁNEĆ (Tseycum, Tsartlip, Tsawout, Pauquachin), Ts-ou'ke, Scia'new and Snuneymuxw Nations. Several (though not all) of these historic treaty First Nations are in modern-day treaty talks under the umbrella of the Te'mexw Treaty Association (including Songhees, Ts-ou'ke, Malahat and their northern neighbours Snaw-naw-as) or independently (Snuneymuxw). The historic Vancouver Island Treaties area is surrounded by the territories of other Coast Salish First Nations who have never entered into a historic treaty relationship (including the Hul'q'umi'num'-speaking communities of Cowichan, Stz'uminus, Penelakut, Halalt, Lyackson, Lake Cowichan First Nations). Most of these First Nations are in modern-day treaty negotiations, and another (Tsawwassen) has concluded a modern-day agreement with provisions that intersect the geographies of the historic Vancouver Island Treaties.

The Vancouver Island Treaties made significant promises, including that treaty signatories' descendants would be at liberty to hunt over the unoccupied lands and to carry on their fisheries as formerly. ${ }^{1}$ I am interested in the ways these historic Vancouver Island Treaties have become bound up in ideas of territory and community, as expressed by both local Indigenous Peoples and the state.

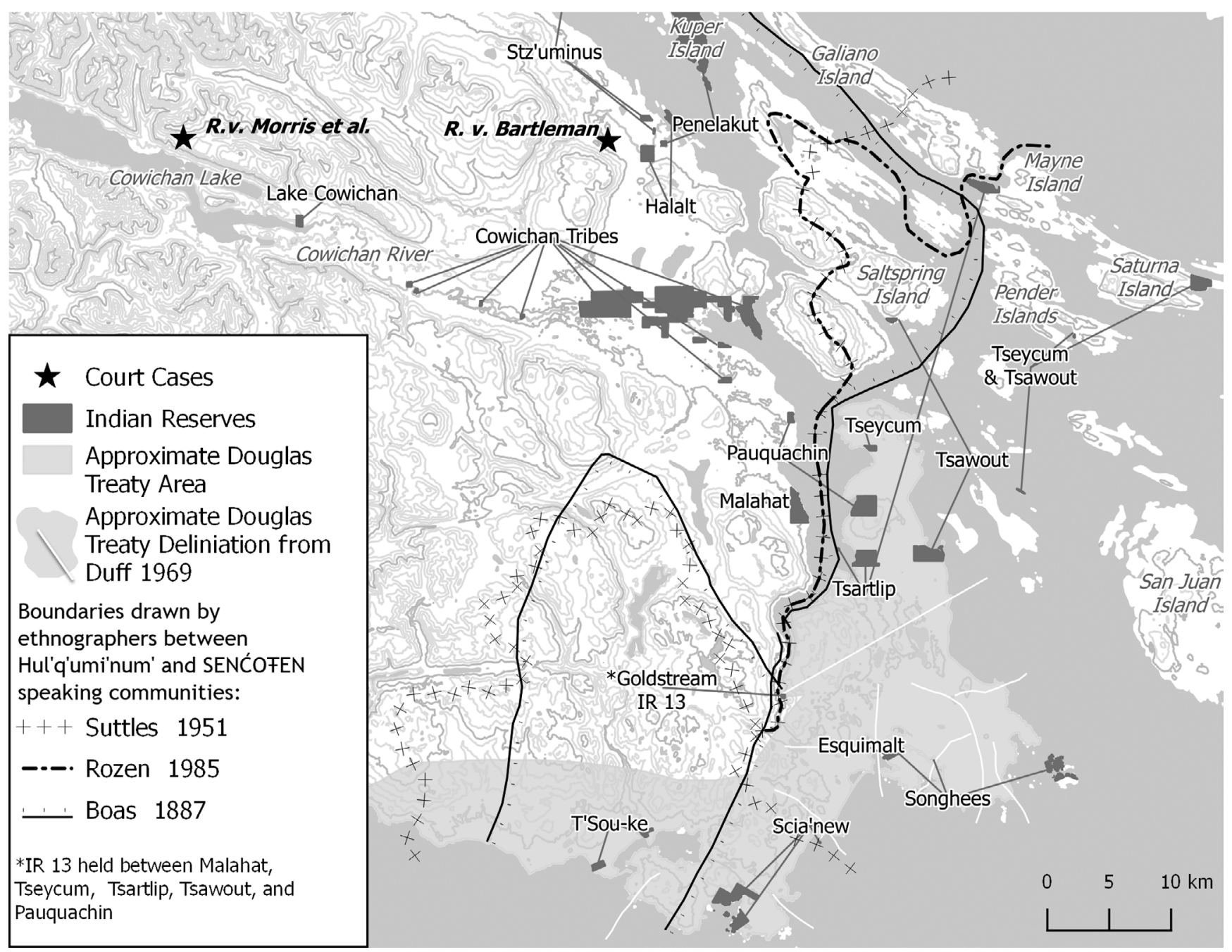

Figure 1: Location of Vancouver Island (Douglas) Treaties hunting cases (stars), areas described in Vancouver Island Treaties (light grey), Indian Reserves (dark grey) and territorial boundaries from classic ethnographies (dashed lines).

Source: Cartography by Brian Thom, assisted by Jack Baker. Territorial boundary lines from classic ethnographies redrawn from Boas (1887), Duff (1969), Rozen (1985) and Suttles (1951). 
In a world where bilateral kin networks are a foundational constituent of community - where territorial prerogatives related to resource harvesting are exercised through idioms of family and community - it makes no sense to me that the state should insist that treaty implementation be predicated on First Nations completely "resolving" their territorial overlaps with tidy, contiguous boundaries. I argue that the state's normal expectation of bounded territorial cartography has done much to contribute to the divisive language of overlapping claims. Courts and other government institutions have perpetuated demands for overly simplified territorial representation, reflecting ongoing colonial relations of power in the expression and negotiation of Indigenous territory (Nadasdy 2012; Quirk 2015; Thom 2009, 2014; Turner and Fondahl 2015). Such expectations have done much to limit the appreciation of Coast Salish peoples' visions of community, to constrain the recognition of Indigenous legal orders, and to thwart the successes of Indigenous political and economic institutions.

For treaty relationships to not get mired in the language of overlaps, a fulsome recognition of Coast Salish self-determination on matters such as how individuals access and navigate territory away from home - that is, who may be considered part of the collective community in matters of exercising rights - is required. In the case of Vancouver Island Treaty territories, such selfdetermination is important as it relates to the ongoing cultural practices of hunting, fishing and other resource harvesting and, by extension, to the way that resource management and urban or industrial development decisions that may affect those rights are made. Indigenous Peoples involved in these treaty relationships, including both those who are signatory to the historic Vancouver Island Treaties and neighbouring non-treaty First Nations, must have the legal and political space to determine the spatial character of their territories, who they are as peoples, what community means in Indigenous terms, and how their communities' exercise of their treaty rights will continue to be guided by Indigenous legal principles.

This article draws on contemporary conversations, testimonies and negotiation frameworks of Coast Salish peoples in and around the southeast corner of Vancouver Island who are working to implement treaty principles in relation to territory and community. I have worked as a researcher and adviser in Hul'q'umi'num' communities over the past two decades and have seen treaty territoriality erupt as overlapping claims discourses in treaty negotiations, park co-management, archaeological site decisions, and innumerable other political and legal contexts, yet also be agreeably navigated in the everyday exercise of a wide range of harvesting and cultural rights. These Hul'q'umi'num'-speaking communities that live in the Cowichan and Chemainus watersheds and Gulf Islands have never signed a historic treaty and have been working to establish respectful relations with Canada in the modern-day treaty process (Thom 2014). Their SENĆOHENspeaking and Lekwungen-speaking neighbours to the south on the Saanich Peninsula and in the metro Victoria area, and the Hul'q'umi'num'-speaking Snuneymuxw community to the north in the Nanaimo area have all been working to implement their historic Vancouver Island Treaties in contemporary contexts (Claxton 2015). In my work in these First Nations' territories, I have come to appreciate how respecting and recognising Indigenous notions of citizenship and local principles for resource management decisions could more fully realise historic and modern-day treaty relationships. Let me begin by briefly highlighting some insights shared with me by Elders of Island Hul'q'umi'num' communities and that have been expressed in the courts by Vancouver Island Treaty community members.

\section{Coast Salish Principles of Sharing}

Sharing food, and in particular sharing access to owned productive resource locales and other places for obtaining food, has long been the Coast Salish moral standard for maintaining a respectful rapport between neighbours and kin (Claxton 2015; Mooney 1976, 1978, 1988; Suttles 1963, 1990b). Coast Salish Elders whom I have worked with whom acknowledge that while "food," in their words, "was taken from all over," people from a host community could always ask someone who was not from the local area, "Why are you here?" with the expectation of hearing about their genealogical connections, good intentions and appropriate local knowledge (Morales and Thom 2020). These principles have similarly been articulated by members of WSÁNEĆ First Nations who are signatories to the Vancouver Island Treaties, and who have had to defend their ongoing exercise of hunting and fishing rights in the courts. In 1984, BC Court of Appeal (BCCA) Justice Lambert recognised the principles that were being explained to him, saying in his reasons for judgment that "it was traditional among the Saanich [WWSÁNEĆ] people to cooperate across tribal and language divisions, sharing access to resources in one another's local territories. Rights to hunt and fish at various locations flowed from family relationships, previous residency, and reciprocal inter-tribal and inter-family arrangements" ( $R v$ Bartleman 1984, para. 33). There is flexibility and agency within this land tenure system, which Justice Lambert picked up on: people may choose to identify not only by their home community - which First Nation they are a member of in today's terms - but also by who their 
family is and where their inherited ancestral name comes from (Kennedy 2007; Thom 2005, 198). This flexibility of expressing one's affiliation not only by the Indian Act rules of band membership but also through Indigenous values of extended family, ancestral titles and residence affiliation is a critical point for understanding how people situate themselves in respect to their rights and responsibilities under Coast Salish land tenure principles.

In this sense, community in the Coast Salish world can be understood as encompassing both extended kin networks and the villages or tribes that are now represented by contemporary political bodies - what Kennedy (2007, 3), drawing on Suttles (1963) referred to as "two sides of a coin." Both extended networks of kin and local village groups have a stake in decision making about how hunting and other practices are conducted on the land, and both are essential to the successful functioning of territorial relations within the society. An individual's emphasis on their family ties may change over time, as marriages, adoptions, residency mobility or other life events weave extended family networks through the Coast Salish world. This is not to say that the Coast Salish world should be thought of as an open-area commons - far from it (Kennedy 2007; Thom 2005). Over time, people may exercise substantial degrees of resourcefulness to succeed in life through their choices of both where they live and how they activate their extended family networks. Self-determining Coast Salish peoples have long accommodated this dynamic practice of citizenship within a framework of recognising principles of territory and land tenure.

This is also not to say that there are no internal debates about these issues. Indeed, in 2001, the late Simon Charlie - a famous Cowichan artist and well-respected Elder - explained these principles of affiliation to me, pointing out the tensions that sometimes come up: "So we didn't just belong to one area. It is the new thing that the Indian Affairs brainwashed our young people that we only come from one place" (qtd. in Thom 2005, 276). His friend, the late Abraham C. Joe, one of the founders of the modern-day land claims movement on southern Vancouver Island, agreed with Simon's sentiment: "Those young people never sat down to realize that their stsa'lum'uqw [great grandparents] were agreeable because they were in-laws. Cowichan married an Indian woman and Indian woman married a Penelakut man. They got along together. That was the purpose for doing that" (qtd. in Thom 2005, 334). In the context of the exercise of treaty rights by Coast Salish peoples in Washington State, legal scholar Russel Barsh (2008, 235) similarly highlighted these emergent tensions, arguing that "the relationship between family and territory has been completely confounded" in cases where individuals and communities have regarded their rights based solely on tribal membership, not accounting for family affiliation.

The state expects a different vision of Indigenous citizenship and territoriality, quite blind to local Indigenous principles of land tenure. The Indian Act requires that individuals declare membership in only one Aboriginal community, and federal policy demands that modern-day land claims citizens be beneficiary of only one treaty. There is no Canadian framework for dual citizenship of Indigenous Nations, no so-called double dipping on treaty rights and benefits. I have heard numerous individuals comment on the difficult position of having a parent or grandparent belong to a Vancouver Island Treaty First Nation while through life circumstance they are a member of a non-Vancouver Island Treaty band. Indeed, the late chief of Cowichan, Dennis Alphonse, when talking about the Vancouver Island Treaties, asked me to note for posterity that he himself was a Vancouver Island Treaty descendant. His grandfather's roots were Lekwungen (Lukw'umun as he said it in Island Hul'q'umi'num' - an Indigenous community in the Victoria area), and his grandmother through his great-grandmother was from Tsawout on the Saanich Peninsula - both Vancouver Island Treaty communities. This never detracted from his strong identity of being descended from the famous Cowichan ancestor Loxe,' (his namesake) and making a lifetime of contributions to his home community as Cowichan Chief, Councillor, Elder and long-time cultural leader. However, he felt that in discussions about treaty rights evoked through frameworks of citizenship under a modern-day treaty that resisted acknowledging his historic Vancouver Island Treaty rights that flow from these ancestors, the government was denying him his full heritage and limiting his life choices and those of his children.

Drawing on well-known principles of Coast Salish bilateral kinship (Suttles 1990a, 463), people like the late Dennis Alphonse feel they should not be forced to choose to be either treaty or non-treaty. They wish to be able to exercise their rights as descendants of multiple communities on a more flexible basis, in accordance with Coast Salish principles and values.

\section{The Vancouver Island Treaties and Hul'q'umi'num' Territory}

Members of the Tsawout, Tsartlip, Tseycum and Pauquachin First Nations, the SENĆOTEN-speaking communities of ẂSÁNEĆ Nation (Claxton 2015; Fritz 2017), have on numerous occasions, over several decades, articulated their understanding of their Vancouver Island Treaty rights to hunt over unoccupied lands as extending well beyond the immediate area of 
their home communities on the Saanich Peninsula (see Figure 1, especially North Saanich and South Saanich treaty areas). Members of these communities have frequently exercised treaty rights in the territories of the Hul'q'umi'num' peoples, First Nations communities that speak a different language and occupy watersheds and Islands to the north of the WSÁNEĆ peoples. These rights are seemingly being exercised beyond boundaries of the conventional "traditional territory" represented by anthropologists and others since the times of Boas (see in Figure 1 the lines showing ethnographic representation of Hul'q'umi'num' and SENĆOFEN territories). Indeed, on numerous occasions over the past 40 years, the Crown has charged WSSÁNEĆ community members for alleged hunting violations when they were asserting their treaty rights to hunt in Hul'q'umi'num' territories. These cases provide insight into the lived experience of contemporary treaty territoriality and the ways that treaty rights might come to be understood in terms that defy simple bounded territory lines on maps.

\section{Inter-Tribal Relationships - Treaty Hunting Rights near the Chemainus River}

In 1977, Joseph Bartleman (a member of Tsartlip) shot and killed a deer on private land at Westholme near the mouth of the Chemainus River, near the Indian Reserves of Halalt, Penelakut and Stz'uminus First Nations, all of which are Hul'q'umi'num'-speaking communities and northern neighbours of this WWSÁNEĆ First Nation. As a member of the Tsartlip, Bartleman's rights to hunt and fish are acknowledged in the North Saanich treaty, which his ancestors signed on the Saanich Peninsula in 1852 (see Figure 1). The trial judge convicted Bartleman in part on the basis that he was "hunting on land outside the geographical limits of the treaty" ( $R v$ Bartleman 1984, para. 2) and therefore could not rely on his treaty right. However, in 1984, the BCCA overturned that ruling, observing that he was hunting "at the invitation of his cousin ... a member of the Halalt people .... within the land formerly occupied by the Halalt people" (para. 5). Relying on testimony from anthropologist Barbara Lane, the judge reasoned that

it was traditional among the Saanich [WSSÁNEĆ] people to co-operate across tribal and language divisions, sharing access to resources in one another's local territories. Rights to hunt and fish at various locations flowed from family relationships, previous residence, and reciprocal inter-tribal or inter-family arrangements ... Hunting by the Saanich [ŴSÁNEĆ] people in the area of Westholme has always been, and still is, based on inter-tribal and inter-family relationships with the Halalt people. (paras. 33, 35)
In his findings, Justice Lambert made a remarkable (for the time, in the mid-1980s) statement of recognition of principles of Indigenous land tenure, incorporating local Coast Salish mechanisms for navigating access to resources into an interpretation of Vancouver Island Treaty rights. His interpretation of hunting rights under the Vancouver Island Treaties was not limited to the very narrow geographic area of the Saanich Peninsula described in the North and South Saanich treaties as the "lands surrendered to the white people forever." Rather, Justice Lambert's reasoning recognises Indigenous legal orders as framing how treaty rights may be exercised within the larger Coast Salish world. Justice Lambert elaborated on his thinking behind this vision of Indigenous territories:

The treaties constituted a continuous patchwork of this small area at the south-eastern extremity of Vancouver Island. None of the ceded lands ... was itself big enough to sustain a hunting or foraging economy for even a comparatively small number of people ... there would have been no protection at all for a hunting and fishing economy for any tribe if its rights to hunt and fish over the neighbouring land of the other tribes were all being extinguished. ( $R v$ Bartleman 1984, para. 51)

Presaging the Supreme Court of Canada's "sufficiency" criteria for Aboriginal title in Tsilhqot'in v British Columbia (2014) by 30 years, Lambert's interpretation of the Vancouver Island Treaties is that WSÁNEĆ territory should not be understood as being constrained to the "ceded lands" described in the historic treaties; such an area would be functionally too small to make sense as Indigenous Peoples' territory. Lambert also avoided framing Indigenous land tenure as a boundless open-access commons, acknowledging, rather, that the treaty right to hunt can be exercised within the context of the continued territorial relations that are meaningful to people on the ground. In this case, the "family relationships, previous residence, and reciprocal inter-tribal or inter-family arrangements" that a WSÁNEĆ person may activate in negotiating territoriality provides the framework for the ongoing exercise of treaty rights $(R v$ Bartleman 1984, para. 33).

While this dynamic interpretation of Vancouver Island Treaty rights creates flexibility for individuals to navigate in their daily lives, it is not completely open-ended. Serious concerns have been expressed by both governments and neighbouring First Nations when individuals take food or involve themselves in land or resource management decisions far from their home communities without engaging in respectful relations with their extended family and neighbours. While these 
kinds of actions certainly cut both ways, individuals from Vancouver Island Treaty communities have, on occasion, as I discuss below, rationalised what we might call extended territory decisions without explicit permission of family or local territorial leaders, arguing that they are exercising their Vancouver Island Treaty rights.

\section{"Extended Treaty Territories" - Elk Hunting at Cowichan Lake}

At Cowichan Lake in the winter of 2001-02, several young hunters - three from Vancouver Island Treaty communities and two from the non-treaty Cowichan Tribes - were charged with killing more elk than they could possibly carry or eat, leaving considerable meat (47 elk were originally found, including over 20 females) behind in the forest ( $R v$ Morris et al. 2010). In their defence, the hunters from Tsartlip and Songhees (two South Island First Nations; see Figure 1) argued that they had a treaty right to hunt at Cowichan Lake. The two men from Cowichan Tribes who were also in the party argued they had an Aboriginal right to hunt. While the Cowichan Lake watershed is within the traditional territory of the Cowichan Tribes (the largest Indian Band in British Columbia whose reserve lands are along the Cowichan River which drains the lake; see Figure 1), the more geographically distant defendants argued that their right under the Vancouver Island Treaties "allows them to hunt elk at Cowichan Lake pursuant to the practice of bilateral kinship reciprocity amongst Coast Salish Bands" ( $R v$ Morris et al. 2010 , para. 20). In particular, they put forward that "intermarriage between individual members of the Songhees or Tsartlip and the Cowichan, a non-[Vancouver Island Treaty] signatory First Nation, gives them access to the Cowichan's resources and thereby the right to hunt outside of the Songhees or Tsartlip traditional territory" (para. 42). Simply having a "family connection in any Coast Salish territory," they argued, would be sufficient "to consider their lands as part of their traditional territory" (para. 45). In particular, they contended that "Cowichan territory should be considered part of the Songhees and Tsartlip extended traditional territories" and that kinship relationships give an "automatic right to hunt within Cowichan traditional territory without any restrictions or protocol requirements" (paras. 45, 48). In their pleadings, the Songhees and Tsartlip defendants tried to make a particularly broad interpretation of Indigenous law around the bilateral kinship network audible to the courts.

The Crown, looking to press forward with 47 counts of illegal hunting ( 8 of which were proven beyond a reasonable doubt) argued that "the area was not part of their traditional hunting territory prior to contact with Europeans or when the Douglas Treaty [Vancouver Island Treaty] was signed" and so Aboriginal and treaty rights were not a valid defence ( $R v$ Morris et al. 2010, paras. 49-51). Indeed, the entrance to the forest-covered hunting grounds at Cowichan Lake is 100 kilometres from the communities of Songhees and Tsartlip, passing by Malahat, Cowichan Tribes and Lake Cowichan First Nations reserve lands on the way. The Crown continued, saying that rights are held by the collective, not the individual, and, rather than individuals or extended families, the village or the Indian Band is the appropriate entity that holds treaty rights (para. 54). In this view, Indigenous social structures are somewhat obscured by state-ordered Indian Band communities (approximating historic village groups) as the legal authority through which treaty rights must be exercised. Taking up the idea that kinship networks must be activated to exercise extra-territorial treaty rights, the anthropologist for the Crown, John Dewhirst, argued in court that kinship reciprocity "does not give an automatic or unfettered right to another village's resources; it only gives potential access" and "requires a party to comply with certain protocols before accessing resources on other First Nation's territory" (para. 27, original emphasis). Here, the Crown's expert witness worked to temper any interpretation the court might give to the idea that treaty rights may be exercised expansively and without limit through Coast Salish kin networks. Local protocols - formal or informal processes of established practices in local communities - are a constraint on the exercise of those rights. The Crown, in effect, argued that the exercise of Vancouver Island Treaty rights is constrained by Indigenous legal orders.

While the Crown hoped to establish limits to exercising rights under the Vancouver Island Treaties, reigniting the discourse of overlapping territories to generate these constraints, the lawyers for the Tsartlip and Songhees hunters involved responded that treaty rights need to be interpreted in a way that recognises "the signatories intention to incorporate this feature of the culture [kinship reciprocity] into the Douglas Treaty ... even if they were not entitled to hunt at Cowichan Lake at the time of signing" ( $R v$ Morris et al. 2010, para. 43). The Crown's lawyer held that the treaty said nothing about these principles of kinship reciprocity and that they were not part of the terms of the treaty (para. 51). No specific evidence was presented in the court that any Vancouver Island Treaty communities had harvested in and around Cowichan Lake at the time of contact, though the judge did recognise a Cowichan Aboriginal right to hunt there based on historic evidence of Cowichan use and control as far back as the 1860s (para. 259). However, Tsartlip 
and Songhees hunters held that their ancestors who signed the treaty would never have wanted to close off potential opportunities to hunt based on future kinship relations, making kinship reciprocity a key part of how the treaty right to hunt could be exercised.

In this way, the hunters from Tsartlip and Songhees, alongside their legal counsel, articulated the idea of extended territory. They argued that traditional territory comes to be "extended" by the idea that "pursuant to kinship reciprocity, Coast Salish people were able to extend their territory from the actual ceded [by treaty] territory to other areas ... even when there is no evidence of any historical presence at that location" ( $R v$ Morris et al. 2010, para. 45, emphasis added). Territory, in this view, is not conceptualised by either the literal description of lands in the treaty or the conventional ethnographic view of watershed/island "traditional" territories of local villages, Indian Bands or First Nations (see territorial boundary lines by Boas 1887; Rozen 1985; and Suttles 1990a, redrawn in Figure 1). The concept of "extended" territory is generated through the particular genealogies of property-owning extended family networks that dynamically align and realign themselves across the Coast Salish world. While extended family networks have in played an important role in regional Coast Salish economic systems (Suttles 1960, 1963), this vision expresses those networks in territorial terms, presumably with all the constitutionally protected rights, jurisdictions and duties associated with contemporary Indigenous territoriality. In the contemporary Coast Salish world, urbanisation, industrial development of forest lands and highly impacted fisheries (Thom and Johnnie forthcoming) are an important backdrop for the continued foundation for articulating regional kinship connections as fundamental for Indigenous territorial relations (for context, see HTG Case Study n.d.). Where it is no longer possible to harvest sufficient and desirable traditional foods like elk, salmon, shellfish or halibut locally, Coast Salish people living in urbanised or industrialised areas must travel further afield to obtain what they need (Thom 2020). These are the practical realities of how twenty-first-century treaty and Aboriginal rights are exercised in the Coast Salish world.

The idea that the territories of the Songhees and Tsartlip (or other Vancouver Island Treaty communities) would be automatically extended into the Cowichan core areas, given other elements of Coast Salish land tenure, was for many in neighbouring Hul'q'umi'num' communities more than they were willing to accept. As the case unfolded in the court, several of my colleagues and friends from non-treaty Hul'q'umi'num' communities expressed opposition and resentment toward the defendants' blanket assertions that the Vancouver Island Treaties automatically extended into their home territory. One friend from a Hul'q'umi'num' community commented to me during the case, "How far do they push their rights in our area, and how free are we to go into their territory and take their elk or deer, or what have you?"' These Hul'q'umi'num' community members were concerned that if this position were accepted by the courts, colonial governments would do further harm to their non-treaty First Nations by "giving those Douglas Treaty people rights" in areas which they felt were ultimately local responsibilities. One person I spoke with resentfully said, "They [Vancouver Island Treaty First Nation members] come here day or night because of that treaty. The government defined their hunting rights, so they infringe on our territory." Automatically extending the territories of a treaty First Nation into non-treaty areas would, in their view, exceed the expectations that normal Coast Salish relations should follow local protocols and territorial prerogatives. The late Angus Smith, a widely respected Cowichan Elder, gave testimony under cross examination to the effect that families and non-members would need to ask permission to use an owned hunting territory ( $R v$ Morris et al. 2010, paras. 186-188). Elders from Tsartlip (Mr Bartleman) and Songhees (Chief Ron Sam) also testified that giving notice for use in another territory is a "traditional teaching" (Bartleman), and to "ask for permission" to harvest at a neighbouring First Nations' site is expected (Sam). Similarly, the Crown argued that any exercise of treaty rights "outside of a traditional territory" (para. 170) should come with "the requirement that permission be sought before any right to access resource be exercised" (para. 169).

My own observations of the ways that community members navigate the exercise of their harvesting rights across the broader Coast Salish landscape echoes the testimony of these Elders. Taking food involves a series of relationships with local families and leaders who are stewarding the resources. This might be through a call to the band office's Lands Department before leaving or checking in with an acknowledged local family member who engages with the land, fish and animals. These practices are not isolated incidents but happen over a person's lifetime. As Arvid Luschiim Charlie explained to me, sometimes people from far away would need explicit permission; sometimes they would have access based on what he characterised as a "general understanding" that local people have of the relationship of the visitors' family to the territory (qtd. in Thom 2005, 378). This is consistent with ethnographic accounts across Coast Salish territories in the nineteenth and twentieth centuries. 
Boas $(1890,833)$, for instance, noted that access to these sites was controlled, as "each gens [Boas's term for residence group] has its proper hunting and fishing grounds, upon which neither members of other tribes nor of other gentes must intrude except by special permission" (see also Hill-Tout 1904, 316; Suttles 1955, 26; 1960, 300). Formal permissions are not the only mechanism regulating these principles of access; also included are the detailed knowledge and cultural teachings necessary to conduct oneself successfully (Lane 1953, 76; Suttles 1951, 110, 397).

These territories are relational networks. As an individual, knowing who one's family is and maintaining those connections and relationships across generations opens important possibilities within the idiom of sharing between kin (Thom 2009). Extending territories comes through relational acts, including obtaining permissions, taking up residence, carrying a local Indian name, learning, and respecting site-specific local ecological and ritual knowledge in the context of having "the teachings" (the common English gloss for the Hul'q'umi'num' concept snuw'uy'ulh) passed on. Territoriality is grounded and limited by these local concerns and actions. Local people steward, control, make decisions about land - perhaps with occasional exceptions (a number of notable owned fishing and village locations distant from home communities come to mind); this practical, local control trumps overly general "extended territory" assertions.

Consider the implications of this dynamic construction of territory - with kinship and teachings, not residence or demonstrations of land use and occupancy, as the primary means of extending territorial rights and responsibilities. Would legitimately exercising extended territorial prerogatives extend back one generation? Two generations? Five generations? Indefinitely? Cowichan Elder Arvid Luschiim Charlie gave evidence in the case, saying that from his experience, "Only grandchildren of a Cowichan member could hunt at Cowichan Lake because of kinship" ( $R$ v Morris et al. 2010, para. 93). Luschiim's statement suggests a very wide field of people could potentially activate extended territorial rights, drawing on what the defendants in the Morris et al. case characterised as an "implied permission to hunt in these areas, so no notice [to local First Nations] is necessary" (para. 172). How important is residence in exercising Treaty Rights through extended territories? The maternal grandfather of one of the Cowichan defendants is from a prominent Snuneymuxw family, a community that also signed a Vancouver Island Treaty in 1854. In the Morris et al. case, he argued that his Treaty Right to hunt as a descendant of the Snuneymuxw Treaty could be extended to Cowichan Lake. The judge observed that the Cowichan defendant was not a resident of Snuneymuxw First Nation, hinting that in his view, residence affiliation is the key to how potential Vancouver Island Treaty rights are activated (para. 39).

In the end, the judge in this case was given the difficult task of sorting out the extent and limits of the treaty relationship in non-treaty territories. Brought out of the arena of quotidian territorial relationships and ongoing dialogues between Coast Salish families and political leaders, we see the norms and responsibilities of extended family relationships distilled, with adversarial parties evoking the divisive language of overlapping claims. Ultimately, Justice Mackenzie accepted that the principle of kinship reciprocity "was a significant part of Coast Salish culture at the time of signing" of the Vancouver Island Treaties ( $R v$ Morris et al. 2010, para. 78). However, he tempered how he saw kinship reciprocity working in practice, resisting the defendants' claims that their Vancouver Island Treaty Rights would automatically extend their hunting territories based on kinship relationships alone. Following the Crown's logic, he was unable to agree with the defendants that this cultural principle was one that the "signatories intended to include ... as a treaty right" (para. 78). He expressed concerns that this assertion would amount to "unfettered access to the resources of that First Nation [that is, Cowichan Tribes] even though that nation had no involvement in ... the signing of the Douglas Treaties" (para. 48). Justice Mackenzie further reinforced this view: "The Crown is correct when it submits that to allow what is traditional territory to constantly be changing based on new kinship relationships is problematic" (para. 90). In this sense, while the character of Coast Salish land tenure practices are recognisable to the courts, the judge is unable to reconcile the dynamic exercise of treaty rights in a world of local, territorially based Indigenous jurisdictions. This finding appears to answer the concern of my Hul'q'umi'num' friend that automatically extending territory through the exercise of Vancouver Island Treaty Rights would otherwise trump local peoples' territorial authorities; instead, the court found they must be exercised in a way that is consistent with local Indigenous jurisdiction.

Justice McKenzie further constrained his vision of the geographic scope of Vancouver Island Treaty Rights by finding that any exercise of those rights must be "on lands traditionally used for that purpose by the defendants' ancestors" ( $R$ v Morris et al. 2010, para. 79). This would appear to preclude the idea that Vancouver Island Treaty Rights could be exercised in "extended territories" far away from places Coast Salish Peoples had extended 
family connections - perhaps freezing the characterisation of treaty rights, given that modern means of travel has the potential expand relational networks. Justice MacKenzie's conclusions have a very specific geographic scope that he found did not extend outside the core Vancouver Island Treaty lands without the operation of Coast Salish law acting as a constraint. In these cases, the geographies of Vancouver Island Treaties matter.

\section{Treaty Territory and Community in Modern-Day Land Claims}

Modern-day treaty negotiations work to constitutionally recognise harvesting rights, and establish government-to-government relationships like participation in ancestral site and resource management decisions in areas outside the immediate vicinity of a First Nation's title lands. Historic practices related to extended kin networks and land tenure principles simultaneously inform and are constrained by the geographies defined in these modern-day treaty provisions. The Te'mexw Treaty Association's Agreement-in-Principle (2015) - a modern-day land claim being negotiated under the BC Treaty Process by several historic Vancouver Island Treaty communities, including Songhees, Ts'ou-ke, Sc'ianew and Malahat - has provisions that provide for the exercise of treaty hunting rights "outside of the Te'mexw Member First Nation Wildlife Harvest Area throughout Canada in accordance with ... any agreements that are in accordance with Federal and Provincial Law as between a Te'mexw Member First Nation and other aboriginal people" (Te'mexw Treaty Association 2015, 98). In these modern-day treaty agreements, the First Nation Wildlife Harvest Area is generally defined as a core territory beyond the First Nation-owned lands on which Treaty Rights are recognised, typically including the Statement of Intent areas submitted by the First Nation at the outset of negotiations. Under this model, southern Vancouver Island Treaty First Nation communities would have few areas outside the urban core of Victoria where their rights could be exercised without being subject to agreements with other First Nations (see Figure 2). These provisions reveal how contemporary Vancouver Island Treaty leaders are envisioning the exercise of those treaty rights into the future - not just within the narrow confines of lands described in the historic treaties but indeed anywhere in Canada, subject to mutually agreeable arrangements with other First Nations.

In First Nation communities that neighbour those negotiating modern-day treaties, these approaches are often perceived as continuing the legacy of governments "giving rights" to treaty First Nations beyond their core territories, infringing on other First Nations lands and resources. Coast Salish community members I have spoken with have complained that the current treaty process encourages First Nations to "draw lines without talking to each other," reinforcing "hwulnitum [white peoples'] terminology of overlaps." This was exactly the argument made in Cook $v$ Minister of Aboriginal Relations and Reconciliation (2007), when the SENĆOTEN Alliance (which included the four Vancouver Island Treaty First Nations from Saanich Peninsula) made a case against the Tsawwassen Final Agreement for creating harvesting and consultation rights in areas, "that they [the SENĆOFEN] have exclusively used and occupied [including] the Saanich Peninsula, all of the Southern Gulf Islands, Point Roberts, Boundary Bay, and the Lower Fraser River, in the Strait of Georgia, since time immemorial" (para. 146). In this case, the judge Madam Justice Garson was not concerned about any non-exclusive rights set out in the Tsawwassen treaty impacting the exercise of Vancouver Island Treaty. She and found that the parties must negotiate, not litigate their relationship in respect of these rights.

Some Coast Salish communities work to resist and subvert divisive discourses of overlapping claims by setting out in these constitutionally binding agreements the continual recognition of the importance of territorial relationships and the ongoing processes of building strong self-governments with clear protocols and processes for recognising principles of sharing. However, while the provisions in these modern-day treaties create a system for extended territories through agreements between First Nations, they reinforce the bureaucratic social and political order of the Indian Band or First Nation government rather than the extended network of kinship that people rely on within Coast Salish land tenure systems. Despite whatever social orders motivated the commitments made at the time of the signing of the Vancouver Island Treaties, ${ }^{3}$ contemporary Indian Bands have become the de facto centre of self-government for the descendants of the treaty signatories. Justice Davies, in Komoyue Heritage Society v British Columbia (2006), recently confirmed other court decisions that these political bodies indeed represent the collective original Vancouver Island Treaty signatories. While there are tensions within some Coast Salish communities for de-aggregation of family or local groups from these bands (see Barsh 2008; Thom 2010, 48), the issue of who represents the collective rights holders has usually resolved to be the contemporary First Nation government.

Even in this modern-day land claims scenario, First Nations negotiators are working to create space for the recognition of extended family networks within the framework of exercising harvesting rights. In the 


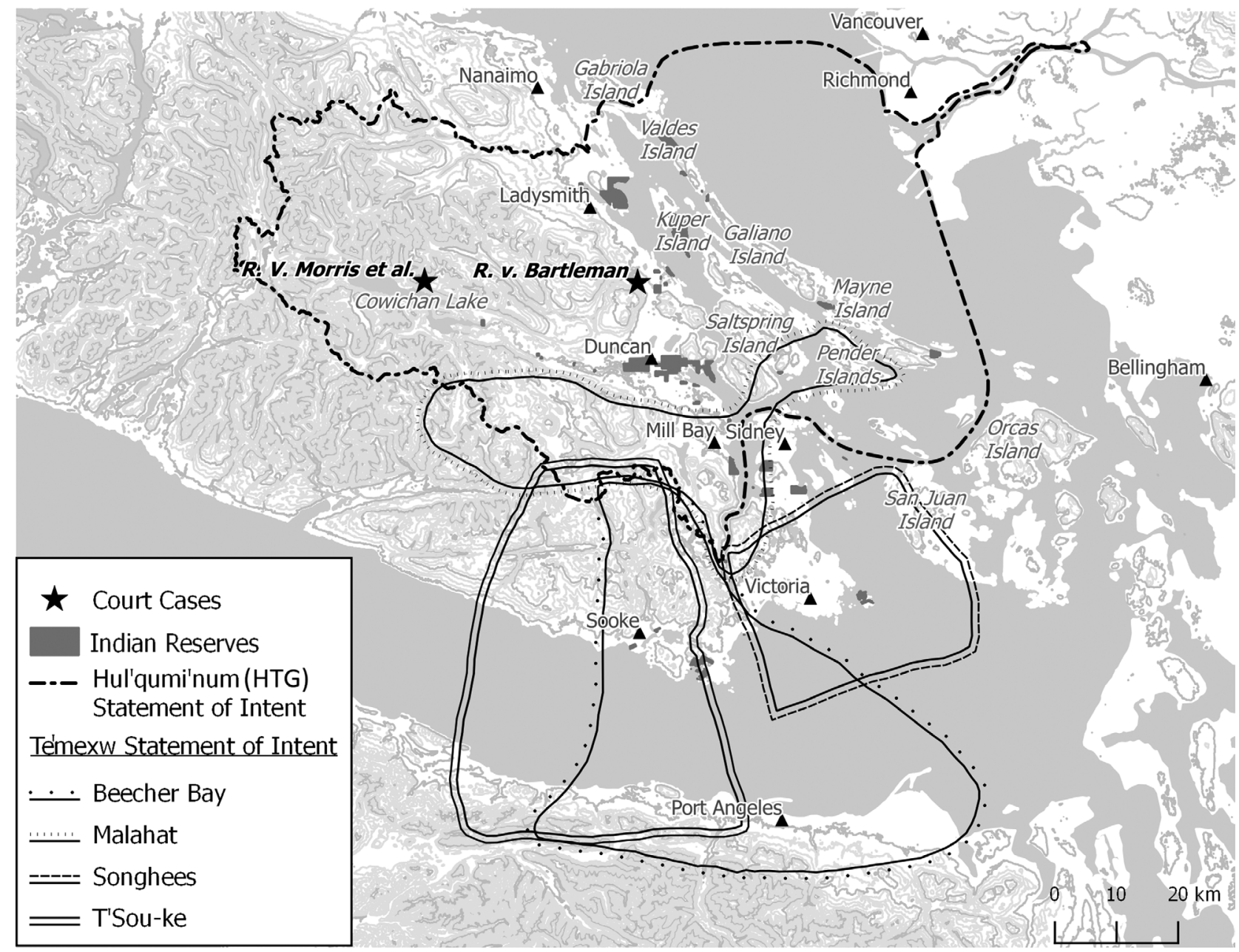

Figure 2: Te'mexw Treaty Association Agreement-in-Principle (2015) First Nations Areas (South Island area only) The lines indicate the territories for negotiation of recognition of land rights, harvest rights, jurisdiction, economic opportunities and consultation.

Source: Cartography by Brian Thom, assisted by Jack Backer. Statement of Intent Lines redrawn from Hul'qumi'num Treaty Group, http://www.hulquminum.bc.ca/pubs/HTG\%20Info\%20Book6.pdf\#page=29, (accessed 23 Jul 2020), and from map by Te'mexw Treaty Association, https://web.archive.org/web/20200127223811/http://www.temexw.org/SOI_Hillshade_E2.pdf (accessed 23 July 2020).

Te'mexw Agreement-in-Principle (which has language that mirrors other Coast Salish modern-day treaty frameworks), First Nations communities have a right to "designate individuals other than Te'mexw Member First Nation Citizens to exercise the Te'mexw Member First Nation Right to Harvest Wildlife on behalf of a Te'mexw Member First Nation Citizen" if the designated person is a "spouse or a child or a grandchild of the Te'mexw Member First Nation Citizen" (Te'mexw Treaty Association 2015, 97). While restricting connections to spouses, children and grandchildren may not exactly mirror the potentially enormous expansive network of Coast Salish kin relations through which rights may be exercised, it does constitutionally entrench the principle of extended kinship connections beyond the local community as a source for exercising treaty rights. On the other hand, modern-day treaty agreements do foreclose on a more fluid, pervasive approach where people could choose their affiliation based on ancestral connections. The Te'mexw Agreement-in-Principle (again, mirroring other agreements) prohibits any notion of dual (or plural) citizenship through prohibiting enrolment under the Final Agreement of any "individual who is a member of a First Nation that is a signatory to a treaty or land claims agreement in Canada or who is a beneficiary under another treaty or land claims agreement in Canada, other than a Douglas Treaty" (Te'mexw Treaty Association 2015,38$)$. Such a clause reveals the state's interest in centralising identity and attendant rights in the nation, not the family. 


\section{Conclusions}

It seems to me that the most elegant solution to the so-called overlapping claims problem is the recognition of Coast Salish self-determination and the continued enabling of the operation of Coast Salish legal orders to both steward the resource and to resolve disputes. Contemporary Indigenous governments, for example, could work to explicitly recognise a land tenure system that included recognising the role of family heads and knowledgeable stewards to make decisions, guide young people and establish repercussions. This would not necessarily be to parcel out sub-territories or allotments to individuals or families - the modern-day treaty process has well demonstrated the difficulty of trying to draw lines between closely related communities. Rather, it could be done through processes in which First Nations develop mechanisms for families, contingent on some criteria of ancestral connection, to register their interests and nominate key individuals who have a stewardship role for those places. First Nations would determine dispute resolution mechanisms appropriate to their communities. The stewards of these places, members of the First Nation whose core territories a given site is in, would be key in making decisions about extended family and other neighbours' access. Agreements would need to be made for the seamless operation of this kind of system in areas like part of the Gulf Islands, where more than one contemporary First Nation has legitimate jurisdictional interests. Importantly, these jurisdictions and authorities must be recognised in communities throughout the Coast Salish world, not just those who enter into land claims agreements with the state. Of course, the challenge of this across the imposed international border that bisects the Coast Salish world is not insignificant (see Miller 2016), but perhaps the United Nations Declaration of the Rights of Indigenous Peoples offers scope for the recognition of Indigenous sovereignties in contexts that cross nation-state boundaries.

In respect of modern-day treaty settlements, rather than respond by further narrowing the already diminished treaty offers in Coast Salish territories, work should be done to find ways to recognise and enable the successful operation of Indigenous self-determination, including the accommodation of these cultural practices and the authority to manage them. In this regard, I believe the full potential of the treaty relationship has so far eluded us.

There is a Coast Salish proverb stated as follows in Hul'q'umi'num': 'uy' ye' thut ch ' $u$ ' suw ts'its'uwatul' ch." It means "take care / respect each other and you will help one another." This essential wisdom provides a way to think about the implementation of the Vancouver Island Treaties without evoking the divisive language of overlapping claims. Indigenous communities that are in a position of abundance with respect to their territories have the opportunity to continue to facilitate sharing across extended family relations, respecting long-standing social and legal orders. Governments need to be supportive partners, recognising how and when they are putting First Nations into irreconcilable "overlapping" positions. When this does occur, they must provide important resources to facilitate productive dialogues and the exercise of Indigenous jurisdictions. Those resources must not come with strings attached, or the expectation that perfect boundaries will neatly divide related communities. Rather, for these to continue to unfold in Indigenous terms, successful treaty relationships must be based on the recognition of Indigenous priorities in social and political relations and the making of space by governments. To more fully engage Coast Salish values of respectful sharing relations, respect for the ongoing operation of Indigenous law and cultural practice and a corresponding end to the divisive language of overlaps must be at the root of treaty relationships.

Huy tseep' q'u, si'em ne siyeyu. Nits' huy'. Thank you for hearing these words, respected readers.

Brian Thom, Department of Anthropology, University of Victoria, Victoria, British Columbia, Canada. Email:bthom@uvic.ca.

\section{Acknowledgements}

I dedicate this article to the late Joey Caro, a Penelakut Elder, close colleague and friend. Joey constantly urged me to think about the challenges of so-called overlapping claims and pushed us all to try to creatively and sensitively move away from these confounding discourses and toward a better future of rights recognition. This work was also inspired by the great fortune I had to work with and learn from the Hul'qumi'num Treaty Group from 2000 to 2010, including Robert Morales, the Board of Directors, members of the Elders Advisory Board and other fellow staff. I am particularly grateful to the late Simon Charlie, Abraham C. Joe, Dennis Alphone and Angus Smith, as well as Arvid Charlie. These gentlemen were also all friends of Joey Caro, sharing many of his concerns, and were the foundation of insights for this essay.

This article was originally developed as part of the dialogue between Vancouver Island Treaties communities in the 2012 forum hosted by Snuneymuxw First Nation, which can be viewed on YouTube (http://youtu. be/BknwkHf5ku0?t=17m45s). I recognise that these are 
sensitive legal and political issues, and I want to be clear that this research and analysis reflects my own views, and I do not intend for it to speak for any communities. This work should be taken as without prejudice to the rights and title of any of the Indigenous communities mentioned or implied.

\section{Notes}

1 The full written texts of the various Vancouver Island treaties have been transcribed by Verspoor (2012).

2 All of the anonymized, paraphrased quotes are from my fieldnotes taken in 2005.

3 We should be reminded here of anthropologist Wilson Duff's $(1969,52)$ famous comment that these treaties contained "ethnographic absurdities" in respect of Douglas's problematic view of which group or community owned what particular areas of land.

\section{References}

Barsh, Russel. 2008. "Ethnogenesis and Ethnonationalism from Competing Treaty Claims.” In The Power of Promises: Rethinking Indian Treaties in the Pacific Northwest, edited by Alexandra Harmon, 215-243. Seattle: University of Washington Press.

$R v$ Bartleman, [1984] CanLII 547 (BCCA). Accessed 26 September 2018. http://canlii.ca/t/22whw.

Boas, Franz. 1887. "Zur Ethnologie Britisch-Kolumbiens." Petermanns Geographische Mitteilungen 33 (5): 129-133.

—. 1890. "First General Report on the Indians of British Columbia." In Report of the Fifty Ninth Meeting of the British Association for the Advancement of Science, 801-855. London: British Association for the Advancement of Science.

Claxton, Nicholas XEMTOLTW. 2015. To Fish as Formerly: A Resurgent Journey Back to the Saanich Reef Net Fishery. PhD dissertation, Department of Curriculum and Instruction, University of Victoria. http://hdl.handle. net/1828/6614.

Cook $v$ Minister of Aboriginal Relations and Reconciliation, [2007] BCSC 1722, Accessed 3 February 2019. http://canlii. ca/t/1tzsj9.

Duff, Wilson. 1969. "The Fort Victoria Treaties." BC Studies 3: 3-57. https://doi.org/10.14288/bcs.v0i3.607.

Foster, Hamar. 1989. "The Saanichton Bay Marina Case: Imperial Law, Colonial History and Competing Theories of Aboriginal Title." UBC Law Review 23: 629-650.

Fritz, Justin. 2017. The SWELSWÁLET of the WSÁNEĆ Nation: Narratives of a 'Nation (Re)Building Process.' MA thesis, Department of Anthropology, University of Victoria. https://dspace.library.uvic.ca//handle/1828/8842.

Frogner, Raymond. 2010. “'Innocent Legal Fictions': Archival Convention and the North Saanich Treaty of 1852." Archivaria 70: 45-94. https://archivaria.ca/index.php/ archivaria/article/view/13295.

Hill-Tout, Charles. 1904. "Ethnological Report on the Stseélis and Skaúlits Tribes of the Halkomélem Division of the Salish of British Columbia." Journal of the Anthropological Institute of Great Britain and Ireland 34: 311-376. https://doi.org/10.2307/2843105.
HTG Case Study. n.d. Mapping Contemporary Challenges to Island Hul'qumi'num Peoples' Territories. Accessed 21 July 2020. https://sites.google.com/view/htgcasestudy/.

Kennedy, Dorothy. 2007. “Quantifying ‘Two Sides of a Coin’: A Statistical Examination of the Central Coast Salish Social Network.” BC Studies 153: 3-34. https://doi.org/10.14288/ bcs.v0i153.657.

Komoyue Heritage Society v British Columbia (AG), [2006] BCSC 1517, Accessed 3 February 2019. http://canlii. $\mathrm{ca} / \mathrm{t} / 1 \mathrm{ps} 4 \mathrm{~m}$.

Lane, Barbara. 1953. A Comparative and Analytical Study of Some Aspects of Northwest Coast Religion. $\mathrm{PhD}$ dissertation, Department of Anthropology, University of Washington.

Miller, Bruce. 2014. "An Ethnographic View of Legal Entanglements on the Salish Sea Borderlands." UBC Law Review 43 (3): 991-1023.

—_ 2016. The Contemporary Coast Salish: Essays by Bruce Granville Miller. edited by Bruce Miller and Darby Stapp. Memoir 12. Richland, WA: Journal of Northwest Anthropology.

Mooney, Kathleen. 1976. "Social Distance and Exchange: The Coast Salish Case.” Ethnology 15 (4): 323-346. https://oi. org/10.2307/3773303.

—. 1978. "The Effects of Rank and Wealth on Exchange among the Coast Salish.” Ethnology 17 (4): 391-406. https://doi.org/10.2307/3773190.

— . 1988. "Suburban Coast Salish Inter-Household Co-operation, Economics and Religious Movements." Culture 8 (1): 49-59.

Morales, Sarah, and Brian Thom. 2020. "The Principle of Sharing and the Shadow of Canadian Property Law." In Creating Indigenous Property: Power, Rights, and Relationships, edited by Angela Cameron, Sari Graben and Val Napoleon, 120-162. Toronto: University of Toronto Press.

$R v$ Morris et al., [2010] BCPC 270. Accessed 3 February 2019. http://canlii.ca/t/2df6z.

Nadasdy, Paul. 2012. "Boundaries among Kin: Sovereignty, the Modern Treaty Process, and the Rise of EthnoTerritorial Nationalism among Yukon First Nations." Comparative Studies in Society and History 54 (3): 499532. https://doi.org/10.1017/S0010417512000217.

Quirk, Dominique. 2015. Addressing Overlapping Land Claim Conflict: An (Alter)Native Approach. Master's thesis, Faculté de droit, Université de Montréal.

Rozen, David. 1985. Place-Names of the Island Halkomelem Indian People. Master's thesis, Department of Anthropology and Sociology, University of British Columbia. http://hdl.handle.net/2429/25517.

Suttles, Wayne. 1951. The Economic Life of the Coast Salish of Haro and Rosario Straits. $\mathrm{PhD}$ dissertation, University of Washington.

—. 1955. Katzie Ethnographic Notes. Victoria: British Columbia Provincial Museum.

— 1960. "Affinal Ties, Subsistence, and Prestige among the Coast Salish." American Anthropologist 62 (3): 296-305. https://doi.org/10.1525/aa.1960.62.2.02a00080.

—. 1963. "Persistence of Intervillage Ties among the Coast Salish.” Ethnology 2 (4): 512-525. https://doi. org/10.2307/3772960. 
_. 1990a. "Central Coast Salish." In Handbook of North American Indians, vol. 7, Northwest Coast, edited by Wayne Suttles, 453-475. Washington, DC: Smithsonian Institution. - 1990b. "Central Coast Salish Subsistence." Northwest Anthropological Research Notes 24 (2): 147-152.

Te'mexw Treaty Association, Canada, and British Columbia. 2015. "Te'mexw Treaty Association Agreement-inPrinciple.” Accessed 3 February 2019. http://www.bctreaty. ca/sites/default/files/Temexw_AIP.pdf.

Thom, Brian. 2005. Coast Salish Senses of Place: Dwelling, Meaning, Power, Property and Territory in the Coast Salish World. PhD dissertation, Department of Anthropology, McGill University. https://escholarship. megill.ca/concern/theses/vm40xs07v.

_ 2009. "The Paradox of Boundaries in Coast Salish Territories.” Cultural Geographies 16 (2): 179-205. https:// doi.org/10.1177/1474474008101516.

_ 2010. "The Anathema of Aggregation: Towards 21st Century Self-Government in the Coast Salish World." Anthropologica 52 (1): 33-48. https://www.jstor.org/ stable/29545993.

—_. 2014. "Reframing Indigenous Territories: Private Property, Human Rights and Overlapping Claims." American Indian Culture and Research Journal 38 (4): 3-28. https://doi.org/10.17953/aicr.38.4.6372163053512w6x. . 2020. "Encountering Indigenous Law in Canada." In The Oxford Handbook of Law and Anthropologyt, edited by Marie-Claire Foblets, Mark Goodale, Maria Sapignoli and Olaf Zenker. Oxford: Oxford University Press.

Thom, Brian, and Kathleen Johnnie. Forthcoming. "Implementing Contemporary Indigenous Territories: Mapping the Aspirations and Challenges of Island Hul'qumi'num Peoples." In Indigenous Stewardship of Environment and Alternative Development, edited by Evodia Silva-Rivera, Katie Sinclair and Colin Scott. Toronto: University of Toronto Press.

Tsilhqot'in Nation v British Columbia, [2014] 2 SCR 257, 2014 SCC 44. Accessed 3 February 2019. http://canlii.ca/t/ g7mt9.

Turner, Christopher, and Gail Fondahl. 2015. “'Overlapping Claims' to Territory Confronting Treaty-Making in British Columbia: Causes and Implications." Canadian Geographer 59 (4): 474-488. https://doi.org/10.1111/ cag.12205.

Vallance, Neil. 2015. Sharing the Land: The Formation of the Vancouver Island (or 'Douglas') Treaties of 1850-1854 in Historical, Legal and Comparative Context. PhD dissertation, Faculty of Law, University of Victoria. http://hdl. handle.net/1828/7089.

Verspoor, Frederike. 2012. The Fort Victoria and Other Vancouver Island Treaties, 1850-1854. BC Archives MS0772. Accessed 23 July 2020. https:/royalbcmuseum.bc.ca/ assets/FortVictoriaTreaties.pdf. 